\title{
THE LOGICAL AND PRAGMATIC ALGORITHM OF INFERRING EUPHEMISTIC IMPLICATURES IN THE ENGLISH AND UKRAINIAN LANGUAGES
}

\author{
M. G. GOLTSOVA, PhD in Philology, Associate Professor, \\ National University of Life and Environmental Sciences of Ukraine \\ E-mail: mariam88@ukr.net \\ ORCID: 0000-0003-2385-436X
}

\begin{abstract}
This article focuses on euphemistic implicatures in the English and Ukrainian languages inferred from the logical and pragmatic aspects. The general scientific methods, pragmatic analysis, methods of formal logics and model creating are used in order to infer euphemistic implicatures. A logical and pragmatic model is chosen as tertium comparationis of the research. The logical structure of euphemistic implicatures in English and Ukrainian can be modeled in a manner that is isomorphic for the two contrasted languages under analysis. A new logical and pragmatic algorithm designed for inferring euphemistic implicature has been elaborated. The logical operations of implication and conjunction have been applied to infer implicatures from euphemisms in the English and Ukrainian languages.
\end{abstract}

Keywords: implicature, Cooperative principle, euphemistic implicature, logical operation, logical implication, conjunction, logical and pragmatic model, implicature inferring

Introduction. One of the fastestgrowing areas in linguistics is pragmatics. A key question in pragmatics research is the procedure of inferring implicatures. Implicature is a vital pragmatic element in the process of communication which bridges the gap between what is literally said and what is intentionally meant. The logical character of implicatures means that implicature presupposes the information based on logical laws as well as the language capability and encyclopedic knowledge of the interpreter. That is why it is necessary to elaborate a logical and pragmatic algorithm aimed at inferring implicatures. In this research we are going to have a closer look at the euphemistic implicatures and the process of their inferring.

Recent research and publications. Implicature has been the object of numerous linguistic investigations in recent years. Chris Potts observed the logic of conventional implicatures [10]. Craige Roberts analysed a correlation between implicature, presupposition and logical form [11]. Michael Franke explored the extent to which speakers might choose different kinds of implicature triggers in an uncooperative game of communication. Nataliia Kravchenko investigates indirect speech acts' via conversational implicatures and pragmatic presupposition [7] as well as illocution of direct speech acts via conventional implicature and semantic presupposition [8]. Yulia Artemenko studies verbal indicators of implicatures in English discourse [2]. Maria Sydorova analysed linguistic and pragmatic properties of utterances with implicatures in German dialogical discourse [12].

The purpose of this research is to present a logic and pragmatic algorithm for the inferring euphemistic implicatures in the Ukrainian and English languages.

To reach the objective of the research and to accomplish its tasks, a number of general scientific methods (induction, deduction, introspection, analysis) are used. Pragmatic analysis, that takes into account the Gricean maxims, is used for interpretation of pragmatic characteristics of euphemistic implicatures. Scientific method

(C) M. G. Goltsova

«International journal of philology» | «Міжнародний філологічний часопис» Vol. 10, № 2, 2019 
of model creating is applied in order to build logic and pragmatic model of euphemistic implicature. Methods of formal logics helped to infer euphemistic implicatures. The method of contrastive analysis is applied to reveal the unique and similar features of contrasted languages. Logical and pragmatic model is chosen as the basis for comparison or tertium comparationis - an extra-linguistic notion which is not found in any of contrasted languages but is formed by a meta-language by means of deduction.

Results. When people communicate, they tend to follow certain rules to make their message easily understood by all interlocutors. Paul Grice stresses that it is not that we all must follow his Cooperative Principle but that it is reasonable for us to follow it [6, p.29]. Grice created a "general principle which participants will be expected to observe, namely: Make your conversational contribution such as required, at the stage at which it occurs, by the accepted purpose or direction of the talk exchange in which you are engaged" [6, p.26]. Grice added four maxims to his Cooperative Principle: the maxims of Quantity, Quality, Relation and Manner. Grice's Cooperative Principle allows interlocutors to infer implicatures that consist of an implicit meaning that goes beyond the explicit linguistic meaning of an utterance.

According to the Grice [6, p. 22], conventional implicature is independent of the Cooperative Principle and its maxims, while conversational implicatures arise due to the violation of its maxims. However, in our research we are going to analyse euphemistic implicatures, which despite being conventional, are still the result of the flouting of Cooperative Principle maxims.

Euphemism can be defined as a mild or indirect word or expression substituted for one considered to be too harsh or blunt when referring to something unpleasant or embarrassing. The word 'euphemism' comes from the Greek word 'euphemo', 'eu' means 'good/well' while 'pheme' means 'speech/speaking'. And thus the literal meaning of 'euphemism' is 'to speak with good words or in a pleasant manner'. $[1$, p. 4]

For the purpose of this research, euphemistic implicature is defined as the inference of an addressee which is created by the decoding of the real sense of the means of secondary nomination with positive connotation that is used to substitute improper, rude or forbidden denotations.

Violation of the maxims of the Cooperative Principle is evident in the use of euphemisms. Grice himself pointed out that the maxims of the Cooperative Principle are not always observed. For example, let us look at the following euphemisms in the English and Ukrainian languages which denote notion of unemployment: at liberty; between jobs; involuntary leisured (people); on the labour; out of work; put on file; resting; sitting by a window; the unwaged; вільний (вільна); у запасі; у резерві; що має свободу вибору; що не отримує зарплатню; що стоїть на обліку.

In these examples we can see the violation of all four maxims of the Cooperative Principle.

The Quantity maxim ("Make your contribution as informative as is required") $[6$, p. 26] is violated due to the fact that polycomponent units (involuntary leisured; що має свободу вибору) are used instead of monocomponent units ('to be unemployed' - 'безробітний').

The Quality Maxim ("Do not say what you believe to be false") [6, p. 27] is violated through overstatement or misrepresentation. Without understanding the meaning of these euphemistic units, an addressee will not be able to interpret their meaning correctly, thus, the information sent by a speaker will be viewed as inadequate. 
The Manner Maxim ("Be perspicuous") [6, p. 27] is violated, as euphemistic expressions could be ambiguous and polysemantic. For instance, an English euphemism 'sitting by a window' is quite inexplicit.

The Relation Maxim ("Be relevant") [6, p. 27] is violated, as the euphemistic expressions without proper background knowledge can be seen as simply irrelevant. English euphemisms may use inappropriate utterances on the surface to express something that the speakers want to say and cannot say.

In this way euphemistic implicatures are created, which an addressee then has to decode, taking into account certain presuppositions, or implicit assumptions about the world or background beliefs.

The understanding of euphemistic implicatures by the addressee may be hindered by unknown words or agnonims. The term 'agnonim' was coined by Morkovkin in his book "Russian agnonims (words we did not know)" [9] and means an unfamiliar word which can cause difficulties in the understanding. For example, such euphemism as shake the pagoda tree ('to make a rapid fortune in India'); stretch the hemp ('to kill by hanging'); having Cupid's measles ('syphilitic') could be agnonims to the interlocutor and arouse misunderstandings.

It should be noted that inferring implicatures is a difficult process which requires using linguistic and logical operation to make inferences about speakers' implied intentions. The current study aims to develop a system for inferring euphemistic implicatures with the help of the logical operations of implication and conjunction, combining logical and pragmatic approaches to implicature.

The concept of logical implication is associated with an operation on two logical values, typically the values of two propositions, that produces a value of false just in case the first operand is true and the second operand is false [3, p. 25]. In the interpretation where $0=$ false and $1=$ true, the truth table associated with the statement "A implies B", symbolized as A $\rightarrow B$, is as follows:

Table 1

Logical implication

\begin{tabular}{|c|c|c|}
\hline$A$ & $B$ & $A \rightarrow B$ \\
\hline 1 & 1 & 1 \\
\hline 1 & 0 & 0 \\
\hline 0 & 1 & 1 \\
\hline 0 & 0 & 1 \\
\hline
\end{tabular}

Logical conjunction is an operation on two logical propositions that produces a value of true if and only if both of its operands are true [3, p. 25]:

Table 2

Logical conjunction

\begin{tabular}{|l|l|l|}
\hline$A$ & $B$ & $A \& B$ \\
\hline 0 & 0 & 0 \\
\hline 0 & 1 & 0 \\
\hline 1 & 0 & 0 \\
\hline 1 & 1 & 1 \\
\hline
\end{tabular}

Let us build a logical and pragmatic algorithm aimed at euphemistic implicature decoding in the English and Ukrainian languages.

The algorithm for interring euphemistic implicatures here consists of six steps. The first step is to define the antecedent, or the first half of a hypothetical proposition, and the consequent of a euphemism. The second one is to build a formal scheme of the euphemistic expression. The third stage is to ascertain the presupposition of the euphemistic expression. After that (stage 4) we have to build a logic and pragmatic model of a euphemistic implicature. The fifth step is to check the correctness of the implicature with the help of a truth table. And the last one (stage 6) is to apply the operation of logical implication and infer an implicature.

(C) M. G. Goltsova

«International journal of philology» | «Міжнародний філологічний часопис» Vol. 10, № 2, 2019 
The logic and pragmatic algorithm of inferring euphemistic implicatures can be illustrated through examples of semantically analogical euphemisms in the English and Ukrainian languages: golden agers; senior citizens; gerontologically advanced; advanced in years; chronologically gifted; having the age of discretion; in one's golden years; in sunset years; in the evening of your days; longer-living; not born yesterday and не першої молодості; що переживає свій золотий вік; (людина), яка повертається з ярмарку; людина $з$ досвідом.

Hence, the antecedents of these expressions are these euphemisms themselves. The consequent is their lexical meaning 'an old person', which is the same in both languages. The formal representation of these euphemistic implicatures is expressed by their antecedents $(A)$.

After that we have to define the presupposition of these expressions. The presupposition is our background knowledge that these euphemisms refers to the notion 'an old person', so the presupposition can be written as $A$ implies $B(A \rightarrow B)$.

It is worth mentioning that implication for presupposition is not bidirectional, that is $A \rightarrow B$ ( $A$ implies $B$ ), as $A$ is the only one variant of many other possible ways of expressing $B$, so we could not identify $A$ and $B$. For example, there some euphemism $(A)$ with the lexical meaning 'dead' (B) in the Ukrainian language: на лаві; який залишив світ; який заснув; який спить вічним СНом; якого покликав Бог; якого прийняв до себе Бог; якому світа не відати. In the English language the same notion could be expressed with the following euphemisms: at rest; at the last day; church triumphant; relieved of suffering; take to God's bosom; who closed his / her eyes; who departed this life; who entered a higher state of existence; who exchanged this life for the better; who passed beyond the veil; who passed into the next world; who passed to the other side of the great Divide; who passed to the other side of the Jordan; who passed to the other side of the Styx; who rang eight bells; who returned to ashes; who returned to the Mother of all things etc. In order to decode euphemistic implicature, one should possess certain language competence which will help to understand certain communicative situations.

The logical and pragmatic model of the euphemistic implicatures що спить вічним сном and who exchanged this life for the better we can present in the form of conjunction of the antecedent with presupposition from which we could get the value of the consequent: $A \&(A \rightarrow B) \rightarrow B$, where $A=$ що спить вічним сном and who exchanged this life for the better; $(A \rightarrow B)=$ presupposition; $B=$ 'dead'.

The last stage of the logical and pragmatic algorithm is to build a truth table for these euphemistic implicatures. A truth table can be used to show whether a propositional expression is true for all legitimate input values; that is, logically valid. A truth table has one column for each input variable (in our case, A antecedent; $\mathrm{B}$ - consequent; $\mathrm{P}$ presupposition which equals $A \rightarrow B$ ), and one final column showing all of the possible results of the logical operation that the table represents $(A \&(A \rightarrow B) \rightarrow B)$. Each row of the truth table contains one possible configuration of the input variables (for instance, $A=$ true $(T) ; B=$ false $(F)$, and the result of the operation for those values.

The following truth table is a demonstration of two euphemistic implicatures "який спить вічним сном " and "who exchanged this life for the better" in the Ukrainian and English languages. As we could see from Table 3, the logical and pragmatic model of euphemistic implicatures, the implicature is always true.

(C) M. G. Goltsova

«International journal of philology» | «Міжнародний філологічний часопис» Vol. 10, № 2, 2019 
Analogically, using the same algorithm, we could analyze other euphemistic expressions: careless of integrity;

Table 3

Truth table for euphemistic implicatures of expressions "що спить вічним сном " and "who exchanged this life for the better"

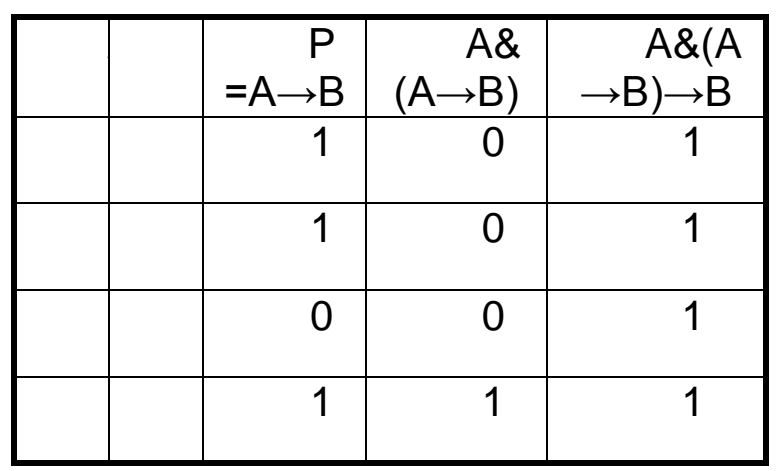

economical with the truth; martyr to selective amnesia; stranger to the truth; who admits poetic truth; who gives controversial information; who gives selective facts; who has failure of memory; with credibility gap. The euphemistic implicature of all these expressions is the lexical meaning - 'a liar'.

Conclusion and perspectives. In modern linguistic implicatures are viewed from a pragmatic position. Grice's theory of implicature is still the cornerstone of the most influential approach to pragmatics at present. In our research we have examined the particular procedure of euphemistic implicature inferring. We have built a logic and pragmatic model of the euphemistic implicature which is represented by $(A \&(A \rightarrow B) \rightarrow B)$. As we can see, the logic and pragmatic model of euphemistic implicatures is identical for the English and Ukrainian languages, which indicates some isomorphic features of the contrasted languages. In a broader perspective it suggests a universal character and structural integrity of implicature in language.

The analyzed linguistic material can become the basis for further pragmatic research of other types of implicatures in the Ukrainian and English languages, for instance, allegorical, circumlocutory, tautological, elliptical, allusive, sarcastic, ironic, hyperbolic, idiomatic implicatures.

\section{References}

1. Allen, K., \& Burridge, K. (1991). Euphemism and dysphemism: Language used as shield and weapon. Oxford, UK: Oxford University Press, 263.

2. Artemenko Yu. O. (2015) Diieslivni indykatory implikatur $\mathrm{v}$ anhlomovnomu dyskursi: strukturno-semantychnyi ta linhvoprahmatychnyi aspekty [Verbal indicators of implicatures in English discourse: structural, semantic and pragmatic aspects]. $\mathrm{PhD}$ thesis. Kremenchuk, 259 c. [in Ukrainian].

3. Brown, Frank Markham (1990), Boolean Reasoning : The Logic of Boolean Equations, Kluwer Academic Publishers, Norwell, MA, 276.

4. Franke M. (2009) Signal to act : game theory in pragmatics. PhD thesis. Amsterdam: Institute for Logic, Language and Computation, 304.

5. Grice H. P. (1991). Futher Notes on Logic and Conversation. Studies in the Way of Words, 41-57.

6. Grice H. P. (1991). Logic and Conversation. Studies in the Way of Words, 22-40.

7. Kravchenko N.K. (2017). Indirect speech acts' via conversational implicatures and pragmatic presuppositions. Cognition, communication, discourse, Vol. 14, 54-66.

8. Kravchenko, N.K. (2017a). Illocution of direct speech acts via conventional implicature and semantic presupposition. Lege artis. Language yesterday, today, tomorrow. The Journal of University of SS Cyril and Methodius in Trnava. Warsaw: De Gruyter Open, Vol. II(1), 128-168.

9. Morkovkyn V. (1997). Russkie agnonimy (slova, kotorye my ne znaem)

(C) M. G. Goltsova

«International journal of philology» | «Міжнародний філологічний часопис» Vol. 10, № 2, 2019 
[Russian agnonims (words we did not know)]. Moscow, AO "Astra sem", 414.

10. Potts, Ch. (2005). The Logic of Conversational Implicatures. Oxford University Press, Oxford, 249.

11. Roberts C. (2012). Only, Presupposition and Implicature. Pragmatics II: Critical Concepts in Linguistics. Vol. II. London, New York : Routledge, 169-221.
12. Sydorova M. O. (2015) Linhvoprahmatychni vlastyvosti vyslovlen z implikaturamy u reaktyvnykh khodakh nimetskomovnoho dialohichnoho dyskursu: [Linguistic and pragmatic properties of utterances with implicatures in responsive moves of German dialogical discourse]. PhD thesis. Kharkiv, V.N. Karazin Kharkiv National University, 259 [in Ukrainian].

\section{ЛОГІКО-ПРАГМАТИЧНИЙ АЛГОРИТМ ВИВЕДЕННЯ ЕВФЕМІСТИЧНИХ ІМПЛІКАТУР В АНГЛІЙСЬКІЙ ТА УКРАЇНСЬКІЙ \\ MOBAX}

М. Г. Гольцова

Анотація. У статті на основі логіко-прагматичного підходу розглядається алгоритм розкодування евфемістичної імплікатури в англійській та українській мовах в контрастивному аспекті, де в якості tertium comparationis була обрана логіко-прагматична модель. Було представлено комплексну методику виведення імплікатур в англійській та українській мовах у логіко-прагматичному та контрастивному аспектах. Загальнонаукові методи (опис, індукція, дедукція, інтроспекція) були використані для відбору й аналізу мовного матеріалу та викладу положень дослідження. Метод лінгвістичної дефрініції використано для визначення поняття евфемістичної імплікатури. Формально-логічні методи слугували вагомими інструментами розкодування імплікатур. Було запропоновано авторський логіко-прагматичний алгоритм виведення імплікатур, що складається з шести етапів: 1) визначення антецедента та консеквента висловлювання; 2) формалізація запису висловлювання за допомогою операції логічної імплікації; 3) визначення конкретної пресупозиції висловлювання; 4) запис логіко-прагматичної моделі імплікатури; 5) перевірка достовірності імплікатури за допомогою таблиці істинності для імплікації із врахуванням пресупозиції; 6) виведення імплікатури як остаточного імплікативного висновку.

У науковій розвідиі при зіставленні логіко-прагматичних моделей евсремістичних імплікатур в англійській та украӥнській мовах було виявлено, що логіко-прагматичні моделі мають ізоморфне формальне вираження в порівнюваних мовах.

Ключові слова: імплікатура, Принцип Кооперації, евфремістична імплікатура, логічна операція імплікації, логіко-прагматична модель, антецедент, консеквент

(C) M. G. Goltsova

«International journal of philology» | «Міжнародний філологічний часопис» Vol. 10, № 2, 2019 